\title{
Symposium review: Comparisons of feed and milk nitrogen efficiency and carbon emissions in organic versus conventional dairy production systems*
}

\section{A. F. Brito† $\odot$ and L. H. P. Silva ${ }^{\circ}$}

Department of Agriculture, Nutrition, and Food Systems, University of New Hampshire, Durham 03824

\begin{abstract}
Evaluation of feed efficiency (FE; calculated as energy-corrected milk yield/dry matter intake) and milk nitrogen efficiency (MNE; calculated as milk $\mathrm{N}$ yield/N intake) is needed to help farmers make decisions regarding the economic and environmental sustainability of dairy farms. Our primary objective was to compare FE and MNE data obtained from studies conducted with organic versus conventional dairy cows. Specifically, 3 data sets were constructed to meet this goal: (1) the organic Jersey data set (ORG-JE) built with studies ( $\mathrm{n}=$ 11) done at the University of New Hampshire BurleyDemeritt Organic Dairy Research Farm (Lee, NH), (2) the conventional Jersey data set (CON-JE) constructed using 19 experiments reported in the literature, and (3) the organic non-Jersey-breed (mostly Holstein, Swedish Red, and Norwegian Red) data set (ORG-NJE) created with 11 published studies. Comparisons were made between ORG-JE and CON-JE and between ORG-JE and ORG-NJE. A second objective was to compare the enteric methane $\left(\mathrm{CH}_{4}\right)$ emission data set from studies using organic Jerseys $(\mathrm{n}=5)$ with those using conventional Jerseys $(\mathrm{n}=4)$. Cows used in the ORG-JE data set had lower $\mathrm{FE}(-16 \%)$ and $\mathrm{MNE}(-15.5 \%)$ than cows used in the CON-JE counterpart, possibly because dry matter intake increased by an average of $10.4 \%$ in organic cows. Feed efficiency and MNE computed from cows belonging to the ORG-NJE data set were intermediate between ORG-JE and CON-JE. Measured $\mathrm{CH}_{4}$ intensity $(\mathrm{g} / \mathrm{kg}$ of energy-corrected milk) from cows in the ORG-JE $\mathrm{CH}_{4}$ data set increased by $71 \%$ compared with that from cows in the $\mathrm{CON}-\mathrm{JE} \mathrm{CH}_{4}$ data
\end{abstract}

Received July 9, 2019

Accepted November 2, 2019.

*Presented as part of the Production, Management, and the Environment: Profitability and Sustainability Symposium at the ADSA Annual Meeting, Cincinnati, Ohio, June 2019.

†Corresponding author: andre.brito@unh.edu set. Estimated FE and enteric $\mathrm{CH}_{4}$ emissions revealed that Wisconsin organic dairies with the heaviest reliance on forage sources and longest grazing time during the summer were the least feed efficient and emitted the greatest amount of $\mathrm{CH}_{4}$ per kilogram of energycorrected milk at the animal and whole-farm levels. Overall, the comparisons of $\mathrm{FE}, \mathrm{MNE}$, and enteric $\mathrm{CH}_{4}$ emissions between organic and conventional dairies and within organic systems made in this symposium review should be interpreted cautiously because they are based on study means and small data sets. Research is needed to better characterize the performance, efficiency, profitability, and carbon emissions of forage-based organic dairies in the United States, including the fast-growing "grass-fed" segment, which relies exclusively on forage diets. The effect of large organic dairies on the economic and social sustainability of small and mid-size organic dairy operations nationwide also deserves further investigation.

Key words: energy-corrected milk, Jersey, methane, organic milk

\section{INTRODUCTION}

Organic milk production has been one of the fastest growing segments of organic agriculture in the United States in the last $20 \mathrm{yr}$. According to the 2016 Certified Organic Survey (USDA NASS, 2017), milk was the top organic agriculture commodity in the United States, with annual sales reaching $\$ 1.386$ billion. Production of organic milk averaged 1.83 billion $t$ in the country in 2016 (USDA NASS, 2017), an 18.5\% increase compared with 2015 (USDA NASS, 2016). The number of organic dairy farms $(2,559)$ and cows $(267,523)$ also increased by 12.1 and $16.7 \%$, respectively, in 2016 versus 2015 (USDA NASS, 2016, 2017). Historically, conventional dairy farmers shifted to organic agriculture to improve the economic viability of their operations (Dalton et al., 2008; Stiglbauer et al., 2013; Dailey et al., 2017). In fact, Pereira et al. (2013) reported that obtaining a steady and fair price for milk was among the chief 
concerns identified by northeastern organic dairy farmers in the United States.

Despite the key role of organic milk production in promoting economic development in rural communities in New England and the Midwest (O'Hara and Parsons, 2013), organic dairy agriculture is going through a critical transition in the United States. Currently, rather than facing short supply, organic dairy farmers are dealing with oversupply of organic milk, falling pay prices, tight profit margins, production quotas, and dropped contracts. The reasons for these changes include shifts in consumer purchasing behavior, excessive transition to organic dairy production without a secured buyer, increasingly large herd sizes, and changes in value of milk components. Note that the "grass-fed" milk market is the only growing segment of the organic dairy sector in the country (Flack, 2016). Therefore, it is important to evaluate the performance of organic dairies through metrics such as feed efficiency (FE; calculated as ECM yield/DMI) and milk $\mathrm{N}$ efficiency (MNE; calculated as milk $\mathrm{N}$ yield/N intake) to support best herd management decisions. Feed expenses account for the greatest proportion of the variable costs in organic dairies (Dalton et al., 2008; McBride and Greene, 2009; O'Hara and Parsons, 2013). According to Heinrichs and Ishler (2016), improved FE may decrease production costs, particularly in farms with poor FE $(\leq 1.32)$. However, nutritional and feeding management, stage of lactation, lactation number, and cow comfort and maintenance requirements can independently or collectively affect FE and farm profitability (Heinrichs and Ishler, 2016; de Ondarza and Tricarico, 2017). Improved FE and MNE may also reduce the environmental impact of dairies by lowering enteric methane $\left(\mathrm{CH}_{4}\right)$ emissions and urinary $\mathrm{N}$ excretion (Knapp et al., 2014; Kidane et al., 2018). We are not aware of any peer-reviewed publication that has compared FE, MNE, and enteric $\mathrm{CH}_{4}$ emissions between organic and conventional Jersey cows as well as FE and MNE between organic Jersey and non-Jersey dairy breeds.

The primary objective of this symposium review was to compare FE and MNE data obtained from studies conducted with organic versus conventional dairy cows. Specifically, 3 data sets were constructed to achieve this objective: (1) the organic Jersey data set (ORG-JE) built with studies $(\mathrm{n}=11 ; 7$ published) conducted at the University of New Hampshire Burley-Demeritt Organic Dairy Research Farm (UNH-ODRF), (2) the conventional Jersey data set (CON-JE) constructed using 19 published experiments, and (3) the organic non-Jersey-breed data set (ORG-NJE) created with 11 publications. Comparisons were made between ORGJE and CON-JE and between ORG-JE and ORG-NJE.
A second objective was to compare the enteric $\mathrm{CH}_{4}$ emission data set from studies run at the UNH-ODRF ( $\mathrm{n}=5 ; 1$ published) with published studies from the University of Nebraska (Lincoln) using conventional Jerseys $(\mathrm{n}=4)$. Our overarching goal was to advise management decisions to improve FE and MNE and reduce the environmental impact of organic dairies in the United States using the UNH-ODRF as a case study.

\section{METHODOLOGY}

\section{Literature Search}

Two systematic literature searches were conducted using the advanced search webtool of the Web of Science database (https://clarivate.com/products/web-of -science/). In the first literature search, the key words "Jersey" and "milk production" and "milk yield" and "intake" were used to identify peer-reviewed papers to build the CON-JE data set. The terms "intake" and "organic" and "milk production" and "milk yield" were selected as key words in the second literature search to obtain peer-reviewed articles that reported using organic dairy cows regardless of breed. As the key word "organic" is not limited to organic dairy agriculture, terms such as "organic matter," "organic nutrient," "organic acid," "organic additive," and "organic osmolyte" were filtered out to exclude unrelated studies. In both searches, publication year and language options were selected to return only English papers published from 2000 to 2019.

\section{Study Exclusion Criteria}

The following criteria were used to exclude studies from the 3 data sets. First, studies that lacked individual DMI and milk yield and reported information (e.g., dietary CP, milk fat and protein concentrations) to calculate FE, MNE, and ECM yield were excluded. Second, studies that used crossbred Jerseys were not included in the CON-JE data set, and those that did not report organic certification were not included in the ORG-NJE data set. Third, grazing studies that did not use internal or external markers (e.g., $\mathrm{Cr}_{2} \mathrm{O}_{3}$, alkanes, indigestible NDF, indigestible ADF) to estimate herbage DMI (i.e., grazed forage) from individual cows were not included in any data set because individual DMI is needed to accurately determine FE and MNE. Fourth, studies in which treatments had more than $35 \%$ of corn silage as a proportion of the diet DM were excluded from all data sets because of the limited use of corn silage in organic dairies (Hardie et al., 2014). Finally, experiments conducted during the transition period, 
which coincided with negative energy balance and mobilization of fat and protein reserves, were excluded from all data sets.

\section{Data Sets}

The exclusion criteria reported above resulted in 11, 19, and 11 studies to build the ORG-JE, CON-JE, and ORG-NJE data sets, respectively. Two additional data sets were constructed. The ORG-JE $\mathrm{CH}_{4}$ data set was built using 1 published study (i.e., Antaya et al., 2019) and 4 unpublished experiments conducted at the UNHODRF. Of these 4 unpublished studies, DMI, milk yield and composition, nutrient digestibility, and blood metabolites data from 2 experiments have been published (i.e., Resende et al., 2015; Isenberg et al., 2019). Data from 4 experiments (i.e., Drehmel et al., 2018; Judy et al., 2018, 2019; Reynolds et al., 2019) conducted at the University of Nebraska using conventional Jersey cows were used to create the $\mathrm{CON}-\mathrm{JE} \mathrm{CH}_{4}$ data set.

\section{Calculations and Measurements}

Study means for each variable including FE and MNE were calculated from treatment means. Standard deviation presented herein was obtained from reported standard deviation or computed from the standard error of the mean multiplied by the square root of the sample size of individual studies. Energy-corrected milk yield was computed according to the equation of Orth $(1992)$ as $[0.327 \times$ milk yield $(\mathrm{kg} / \mathrm{d})]+[12.95$ $\times$ milk fat yield $(\mathrm{kg} / \mathrm{d})]+[7.2 \times$ milk protein yield $(\mathrm{kg} / \mathrm{d})]$ using reported milk yield and composition for standardizing ECM yield calculation across all studies. Feed efficiency was calculated by dividing ECM yield by DMI. When not reported in the selected studies, $\mathrm{CP}$ intake $(\mathrm{kg} / \mathrm{d})$ was estimated by multiplying DMI $(\mathrm{kg} / \mathrm{d})$ by the respective treatment $\mathrm{CP}$ concentration and converted to $\mathrm{N}$ intake $(\mathrm{g} / \mathrm{d})$ using the 6.25 conversion factor. Milk $\mathrm{N}$ was computed by dividing milk protein by 6.38 for standardizing MNE calculation for all studies. Milk N efficiency was calculated as estimated milk $\mathrm{N}$ yield divided by reported or estimated $\mathrm{N}$ intake multiplied by 100 .

The portable head chamber gas emission unit (GreenFeed system; C-Lock Inc., Rapid City, SD) was used to measure enteric $\mathrm{CH}_{4}$ production in 4 studies belonging to the ORG-JE $\mathrm{CH}_{4}$ data set following setups and calibrations reported previously (Dorich et al., 2015; Hammond et al., 2015; Gunter and Beck, 2018; Antaya et al., 2019). The sulfur-hexafluoride technique originally described by Johnson et al. (1994) and adapted by Dorich et al. (2015) was used to measure enteric $\mathrm{CH}_{4}$ production in 1 study that was part of the ORG-JE $\mathrm{CH}_{4}$ data set. The headbox-style indirect calorimeters described by Freetly et al. (2006) and Foth et al. (2015) were used to measure $\mathrm{CH}_{4}$ production from studies included in the CON-JE $\mathrm{CH}_{4}$ data set. Methane yield and intensity were calculated as grams of $\mathrm{CH}_{4}$ per kilogram of DMI or grams of $\mathrm{CH}_{4}$ per kilogram of ECM yield, respectively. Methane emissions in liters per day were converted to mass (grams per day) using the ideal gas law and $\mathrm{CH}_{4}$-specific density of $0.717 \mathrm{~g} / \mathrm{L}$ at standard conditions for temperature and pressure as reported previously (Pereira et al., 2015). This conversion was done to make the enteric $\mathrm{CH}_{4}$ emission data sets for ORG-JE and CON-JE comparable.

Detailed descriptions of experimental treatments, types and dietary proportions of forage sources, number of cows per study, and dairy breeds used to build the ORG-JE, CON-JE, and ORG-NJE data sets are presented in Supplemental Tables S1, S2, and S3, respectively, and milk composition data from these 3 data sets are presented in Supplemental Table S4 (https:// doi.org/10.3168/jds.2019-17232).

\section{Limitations}

Comparisons done in this symposium review are limited by the small data sets used, particularly ORG-JE, ORG-NJE, and the enteric $\mathrm{CH}_{4}$ emission data sets for ORG-JE and CON-JE. In addition, the ORG-JE and ORG-JE $\mathrm{CH}_{4}$ data sets were entirely built with studies conducted in a single site, which were restricted to the management, geographic, and climatic conditions of the UNH-ODRF. An additional limitation is that overall study means of individual data sets were used for comparing $\mathrm{FE}, \mathrm{MNE}$, and enteric $\mathrm{CH}_{4}$ emissions, thereby not considering a potential disproportional effect of individual study treatment means on the global data set means. Biases may also have been introduced when using treatment means instead of individual-cow data points to compute FE and MNE. Forage:concentrate ratio $(\mathbf{F}: \mathbf{C})$, grain processing, forage source, DIM, lactation number, and cow maintenance requirements can all affect FE and MNE (Heinrichs and Ishler, 2016; de Ondarza and Tricarico, 2017). Even though some of these factors (e.g., F:C, DIM) were relatively balanced in our analyses, they were not used as covariates or to yield weighed means due to the small number of studies included in the data sets. Our efficiency assessment is further limited by using only 2 indices (i.e., FE, MNE). According to de Ondarza and Tricarico (2017), individual indices do have merit for describing a segment of dairy efficiency, but multiple dairy efficiency metrics should be considered. 
Table 1. Descriptive statistics for variables belonging to 3 data sets used to compare organic versus conventional dairy cows

\begin{tabular}{|c|c|c|c|c|c|}
\hline Item & No. ${ }^{1}$ & Mean & $\mathrm{SD}$ & Minimum & Maximum \\
\hline \multicolumn{6}{|c|}{ Studies with organic Jersey cows } \\
\hline $\mathrm{BW}, \mathrm{kg}$ & 11 & 438 & 30.6 & 386 & 482 \\
\hline DIM & 11 & 109 & 29.6 & 57.5 & 159 \\
\hline DMI, $\%$ of BW & 11 & 4.12 & 0.32 & 3.60 & 4.64 \\
\hline Milk yield, $\mathrm{kg} / \mathrm{d}$ & 11 & 18.6 & 3.46 & 13.3 & 24.0 \\
\hline ECM vield. ${ }^{2} \mathrm{~kg} / \mathrm{d}$ & 11 & 22.9 & 4.83 & 15.1 & 29.5 \\
\hline MUN, mg/dL & 11 & 12.7 & 2.66 & 8.36 & 16.3 \\
\hline Forage, $\%$ of diet DM & 11 & 61.3 & 6.08 & 50.0 & 70.0 \\
\hline Corn silage, $\%$ of diet DM & - & - & - & - & - \\
\hline \multicolumn{6}{|c|}{ Studies with conventional Jersey cows } \\
\hline $\mathrm{BW}, \mathrm{kg}$ & 17 & 415 & 49.1 & 295 & 486 \\
\hline DIM & 16 & 133 & 57.3 & 88.0 & 325 \\
\hline $\mathrm{MNE},{ }^{4} \%$ of $\mathrm{N}$ intake & 19 & 24.5 & 4.80 & 16.7 & 34.1 \\
\hline $\mathrm{N}$ intake, $\mathrm{g} / \mathrm{d}$ & 19 & 457 & 46.2 & 378 & 538 \\
\hline MUN, mg/dL & 11 & 13.7 & 3.78 & 9.47 & 21.1 \\
\hline Forage, $\%$ of diet DM & 19 & 65.3 & 14.6 & 49.6 & 100 \\
\hline Corn silage, $\%$ of diet DM & 8 & 29.5 & 4.21 & 24.7 & 34.4 \\
\hline \multicolumn{6}{|c|}{ Studies with organic non-Jersey dairy cows } \\
\hline $\mathrm{BW}, \mathrm{kg}$ & 7 & 637 & 40.8 & 583 & 683 \\
\hline DIM & 10 & 111 & 39.3 & 66.0 & 203 \\
\hline DMI, $\mathrm{kg} / \mathrm{d}$ & 11 & 18.3 & 1.82 & 15.7 & 21.3 \\
\hline DMI, $\%$ of BW & 7 & 2.93 & 0.26 & 2.64 & 3.40 \\
\hline Milk yield, kg/d & 11 & 24.0 & 3.97 & 18.6 & 33.2 \\
\hline ECM yield, ${ }^{2} \mathrm{~kg} / \mathrm{d}$ & 11 & 25.8 & 3.18 & 20.1 & 30.5 \\
\hline $\mathrm{FE},{ }^{3} \mathrm{~kg} / \mathrm{kg}$ & 11 & 1.41 & 0.15 & 1.02 & 1.56 \\
\hline $\mathrm{MNE},{ }^{4} \%$ of $\mathrm{N}$ intake & 10 & $\begin{array}{l}1.41 \\
26.7\end{array}$ & 2.67 & 22.7 & 30.7 \\
\hline
\end{tabular}

${ }^{1}$ Number of studies.

${ }^{2} \mathrm{ECM}=[0.327 \times$ milk yield $(\mathrm{kg} / \mathrm{d})]+[12.95 \times$ milk fat yield $(\mathrm{kg} / \mathrm{d})]+[7.2 \times$ milk protein yield $(\mathrm{kg} / \mathrm{d})]($ Orth, 1992).

${ }^{3}$ Feed efficiency $(\mathrm{FE})=\mathrm{ECM}$ yield/DMI.

${ }^{4}$ Milk $\mathrm{N}$ efficiency $(\mathrm{MNE})=($ milk $\mathrm{N}$ yield/N intake $) \times 100$.

\section{FEED AND MILK N EFFICIENCY}

\section{Comparison of FE and MNE Between Organic and Conventional Jersey Cows}

Table 1 shows the descriptive statistics of the data sets used in this symposium review, and Figure 1A, B, $\mathrm{C}$, and D presents the overall ORG-JE data set studies mean and the CON-JE data set individual study means for FE, MNE, DMI, and ECM yield, respectively. Feed efficiency and MNE averaged 1.26 (range $=0.88-1.49$ ) and $20.7 \%$ (range $=15.6-25.4 \%$ ), respectively, across the 11 studies of the ORG-JE data set (Table 1; Figure 1A, B). Compared with the CON-JE data set, $\mathrm{FE}$ and MNE were 16 and $15.5 \%$ lower, respectively, in the ORG-JE counterpart. Yields of milk and milk components, DMI, F:C, forage source, grain processing, feed additives, and herd management can all independently or collectively interact with each other to affect $\mathrm{FE}$ and MNE in lactating dairy cows. However, the most outstanding differences between cows used in the ORG-JE and CON-JE data sets were DMI (Table 1; Figure $1 \mathrm{C}$ ) and N intake (Table 1). Organic Jersey cows consumed on average 10.4 and $8.2 \%$ more DM and N, respectively, than those in the CON-JE data set. In addition, no corn silage was fed in the studies conducted at the UNH-ODRF (Table 1; Supplemental Table S1, https://doi.org/10.3168/jds.2019-17232). Therefore, increased DMI in cows from the ORG-JE data set was likely driven by the need for additional energy intake to keep up with lactation demand. Corn silage provides more fermentable energy than grass or mixed grass-le- 
A

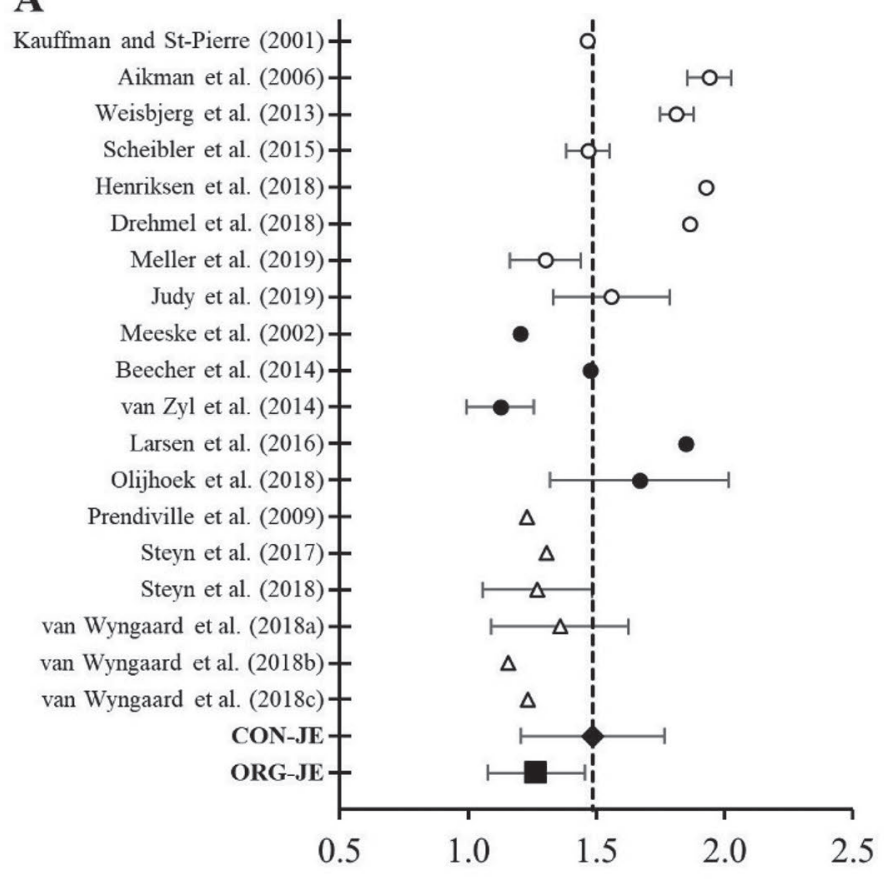

$\mathrm{FE}, \mathrm{kg} / \mathrm{kg}$

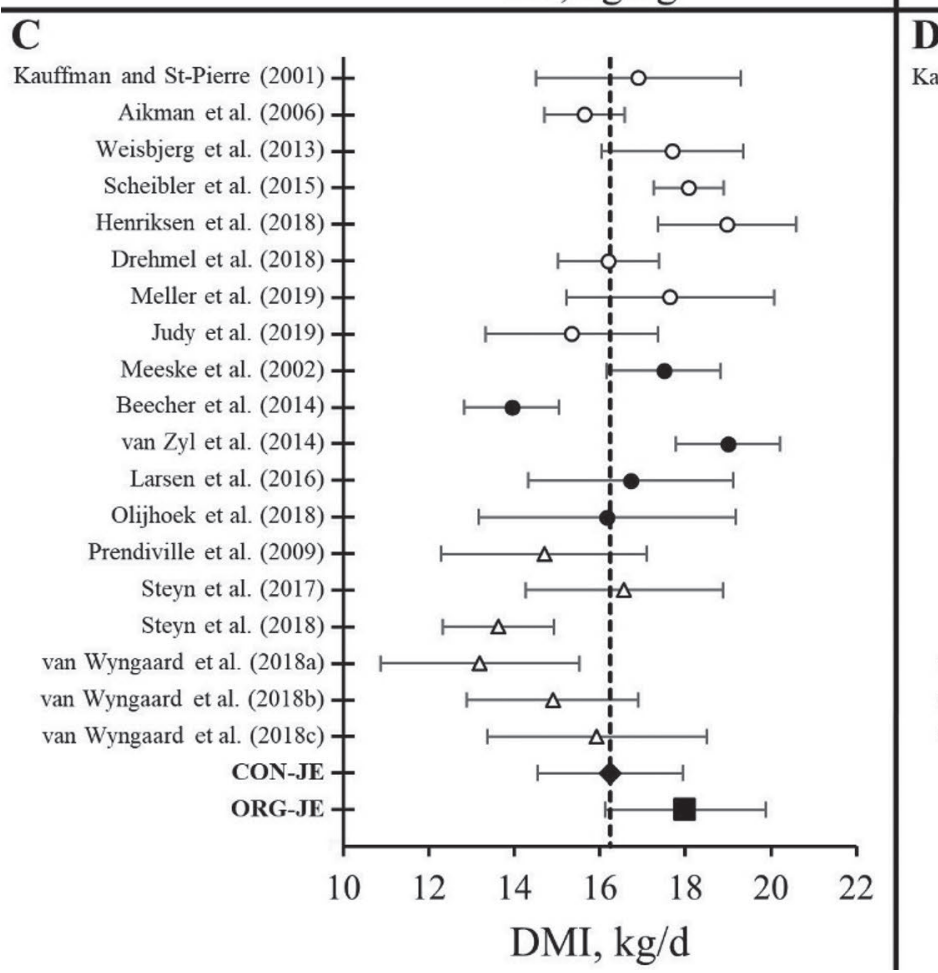

B Kauffman and St-Pierre (2001) Aikman et al. (2006)
Weisbjerg et al. (2013)
Scheibler et al. (2015) Henriksen et al. (2018) Drehmel et al. (2018) Meller et al. (2019) Judy et al. (2019) Meeske et al. (2002) Beecher et al. (2014) van $\mathrm{Zyl}$ et al. (2014) † Larsen et al. (2016) Olijhoek et al. (2018) Prendiville et al. (2009) Steyn et al. (2017) Steyn et al. (2018) van Wyngaard et al. (2018a) van Wyngaard et al. (2018b) van Wyngaard et al. (2018c)

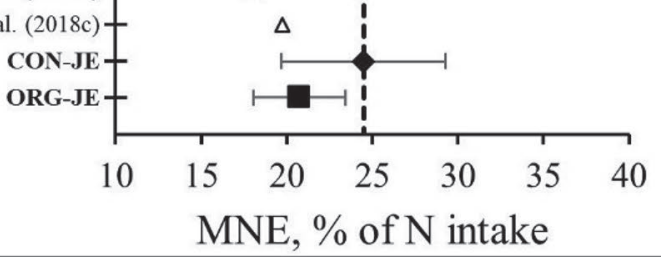
D Kauffman and St-Pierre (2001) † Aikman et al. (2006) Weisbjerg et al. (2013) Scheibler et al. (2015) Henriksen et al. (2018) Drehmel et al. (2018) Meller et al. (2019) Judy et al. (2019) Meeske et al. (2002) Beecher et al. (2014) van $\mathrm{Zyl}$ et al. (2014) Larsen et al. (2016) Olijhoek et al. (2018) Prendiville et al. (2009) Steyn et al. (2017) Steyn et al. (2018) van Wyngaard et al. (2018a) van Wyngaard et al. (2018b) van Wyngaard et al. (2018c) -

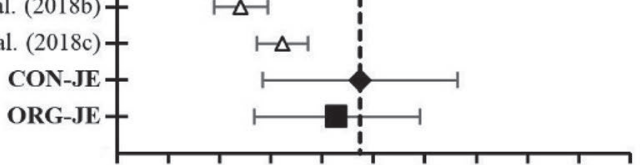

1013161922252831343740 $\mathrm{ECM}, \mathrm{kg} / \mathrm{d}$

Figure 1. (A) Feed efficiency (FE; calculated as ECM yield/DMI), (B) milk N efficiency (MNE; calculated as milk N yield/N intake $\times 100$ ), (C) DMI, and (D) ECM yield of individual study means used in the conventional Jersey cow data set (CON-JE) and the overall studies mean of experiments included in the organic Jersey cow data set (ORG-JE). Open circle $(\bigcirc)$, filled circle $(\bullet)$, and triangle $(\Delta)$ represent studies in which cows were fed corn silage, grass or legume hay or silage, and grazed herbage, respectively. Diamond $(\diamond)$ represents the overall mean from the 19 studies belonging to the CON-JE data set, and square (ם) represents the overall mean from the 11 studies of the ORG-JE data set. Error bars indicate SD reported or calculated from SEM of individual studies. See Appendix 1 for references. 
gume conserved feeds due to a greater concentration of starch, which can ultimately affect $\mathrm{NE}_{\mathrm{L}}$ intake and both FE and MNE.

Six out of 19 experiments used in the CON-JE data set were conducted with grazing cows, whereas only 2 out of 11 studies included in the ORG-JE data set had cows with access to pasture (Figure 1; Supplemental Tables S1 and S2, https://doi.org/10.3168/jds.2019 -17232). Despite the lower number of grazing studies included in the ORG-JE data set, FE and MNE decreased; this further highlights the importance of corn silage in improving nutrient use efficiency in lactating dairy cows. Grazing can reduce FE and MNE due to increased energy expenditure associated with animal activity (Kaufmann et al., 2011). In addition, herbage-based diets often result in excess $\mathrm{N}$ intake or unbalanced supplies of RDP and fermentable energy, which may depress yields of milk and milk components without negatively affecting DMI in the same proportion. On the other hand, 8 out of 11 studies done at the UNH-ODRF were conducted during the winter season with cows exposed to freezing outside air temperatures as well as windy, wet, and snowy conditions. According to USDA National Organic Program regulations, ruminants must have year-round access to the outdoors to comply with organic certification (USDA NOP, 2010). Cold weather may stimulate DMI in lactating dairy cows as a coping mechanism to generate body heat at the expense of production of milk and milk components, ultimately depressing FE and MNE.

\section{Comparison of FE and MNE Between Organic Jersey and Non-Jersey Breeds}

We did not find studies conducted with Jersey cows under organic certification except those performed at the UNH-ODRF. Therefore, FE and MNE evaluation within organic dairy systems was done by comparing the ORG-JE and ORG-NJE data sets. Specifically, the ORG-NJE data set included studies with Holstein ( $\mathrm{n}=$ 5 studies), Swedish Red ( $\mathrm{n}=2$ studies), Norwegian Red ( $\mathrm{n}=2$ studies), and Finnish Ayrshire $(\mathrm{n}=1$ study) cows and 1 study with Red-and-White $\times$ HolsteinFriesian Red crossbreds (Supplemental Table S3, https: //doi.org/10.3168/jds.2019-17232). Whereas FE and ECM yield decreased by 10.6 and $11.2 \%$, respectively, in cows from the ORG-JE data set compared with the ORG-NJE data set, MNE decreased by $22.5 \%$ and DMI was similar (Table 1; Figure 2). This reduction in MNE is intriguing and possibly associated with differences in DMI and $\mathrm{N}$ intake, expressed as a proportion of BW, and whole-body $\mathrm{N}$ utilization. Organic Jersey cows consumed 40.6 and $57.1 \%$ more DM (Table 1) and N (data not shown) relative to their BW, respectively, than those from the ORG-NJE data set, thus suggesting that dietary RDP was supplied in excess of milk protein requirements at $22.5 \%$ lower milk yield (Table 1). Aikman et al. (2008) demonstrated that Jersey cows tended to retain more digestible $\mathrm{N}$ during the dry period than Holstein cows. In contrast, $\mathrm{N}$ balance tended to be more negative at wk 14 after calving in Jersey versus Holstein cows despite body $\mathrm{N}$ being mobilized by both breeds as lactation progressed (Aikman et al., 2008). Furthermore, urinary $\mathrm{N}$ excretion (\% of digested $\mathrm{N}$ intake) tended to be lower in Jerseys than in Holsteins, indicating that these 2 breeds likely respond differently to type and concentration of dietary protein (Aikman et al., 2008). Similarly, Kauffman and St-Pierre (2001) reported that retained $\mathrm{N}$, expressed as a proportion of $\mathrm{N}$ intake or digested $\mathrm{N}$ intake, and productive $\mathrm{N}$ (milk $\mathrm{N}+$ retained $\mathrm{N}, \%$ of $\mathrm{N}$ intake) tended to be lower in Jerseys versus Holsteins. Regardless of breed, organic cows averaged 110 DIM or 15.7 wk of lactation (Table 1), implying that animals used in the ORG-NJE data set better utilized dietary $\mathrm{N}$ than those in the ORGJE data set. However, MUN concentration was 29.8\% lower in the ORG-JE data set than in the ORG-NJE data set. Differences in dairy breeds, $\mathrm{N}$ intake, forage sources, and dietary F:C may have been involved in the discrepancy between MUN and MNE in the ORG-JE and ORG-NJE data sets.

Hardie et al. (2014) used surveys to categorize 69 organic dairy farms from Wisconsin into 4 clusters according to 9 variables related to general farm characteristics, feed supplementation, and proportion of herbage in the diet DM. Using data from Hardie et al. (2014), FE was estimated using the quotient between ECM yield [obtained from reported DHI milk rolling herd average and milk fat and protein concentrations using the equation of Orth (1992)] and predicted DMI according to NRC (2001). This calculation resulted in FE that averaged 1.17 across the 4 clusters. Specifically, cluster 2 had the poorest FE $(0.75 ; \mathrm{n}=5$ farms $)$ followed by cluster 4 (0.97; $\mathrm{n}=24$ farms), likely because these 2 clusters had greater $\mathrm{F}: \mathrm{C}$ and herbage in the diets than clusters 1 ( $\mathrm{n}=8$ farms) and $3(\mathrm{n}=32$ farms), with $\mathrm{FE}$ of 1.25 and 1.34 , respectively. The estimated cluster FE of 1.17 (Hardie et al., 2014) was 7.14 and $17 \%$ lower than that calculated for cows in the ORG-JE (1.26) and ORG-NJE (1.41) data sets, respectively. However, the FE of organic farms in cluster 2 (lowest input system) was 40.5 and $46.8 \%$ lower compared with the ORGJE and ORG-NJE data sets, respectively. Note that Holstein was the predominant dairy breed reported by farmers in the survey of Hardie et al. (2014) and was present in dairies from clusters 1,3 , and 4 . In addition to inaccuracies associated with prediction of DMI, differences in herd management (commercial vs. research 
A

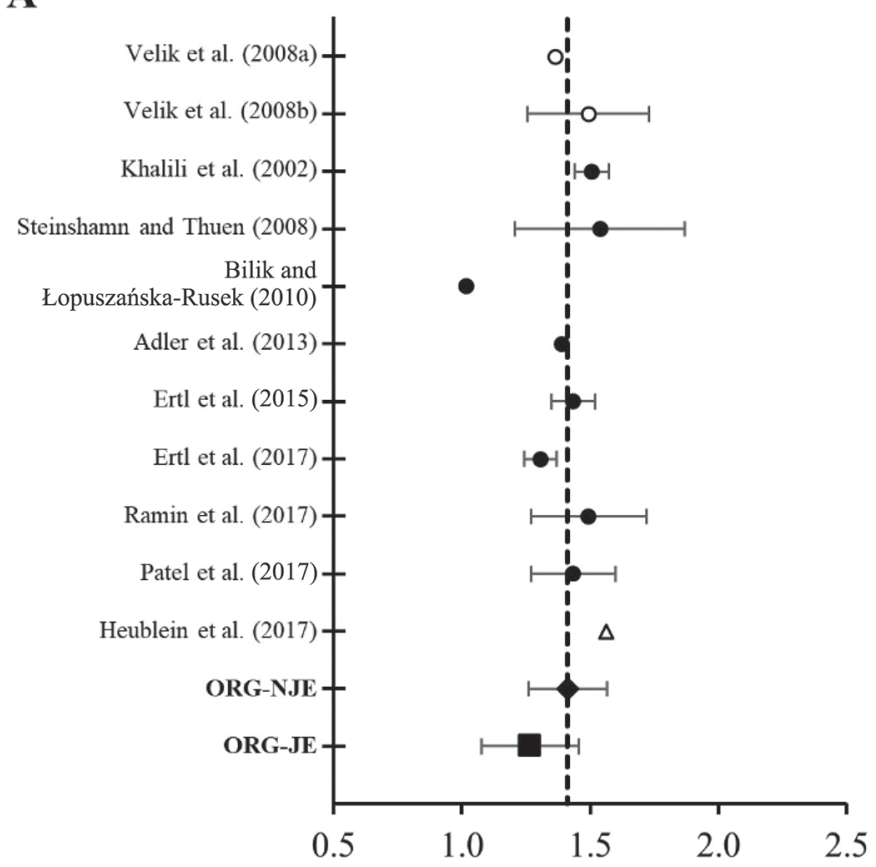

$\mathrm{FE}, \mathrm{kg} / \mathrm{kg}$

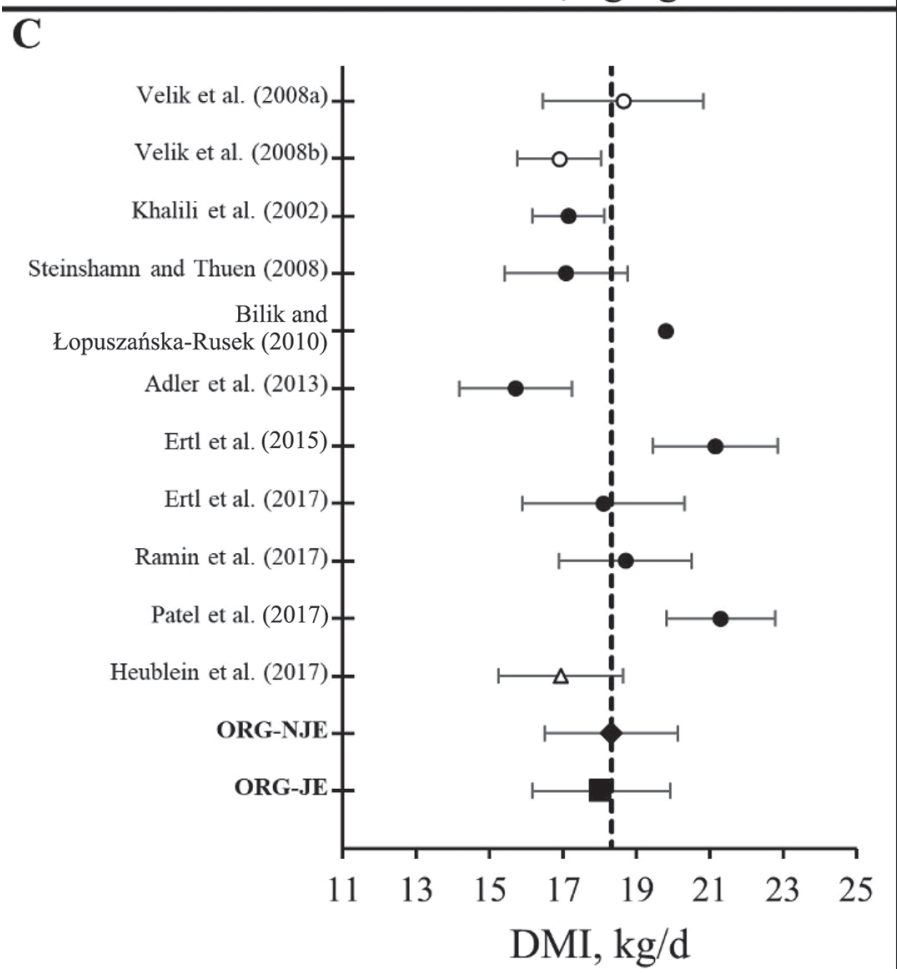

B

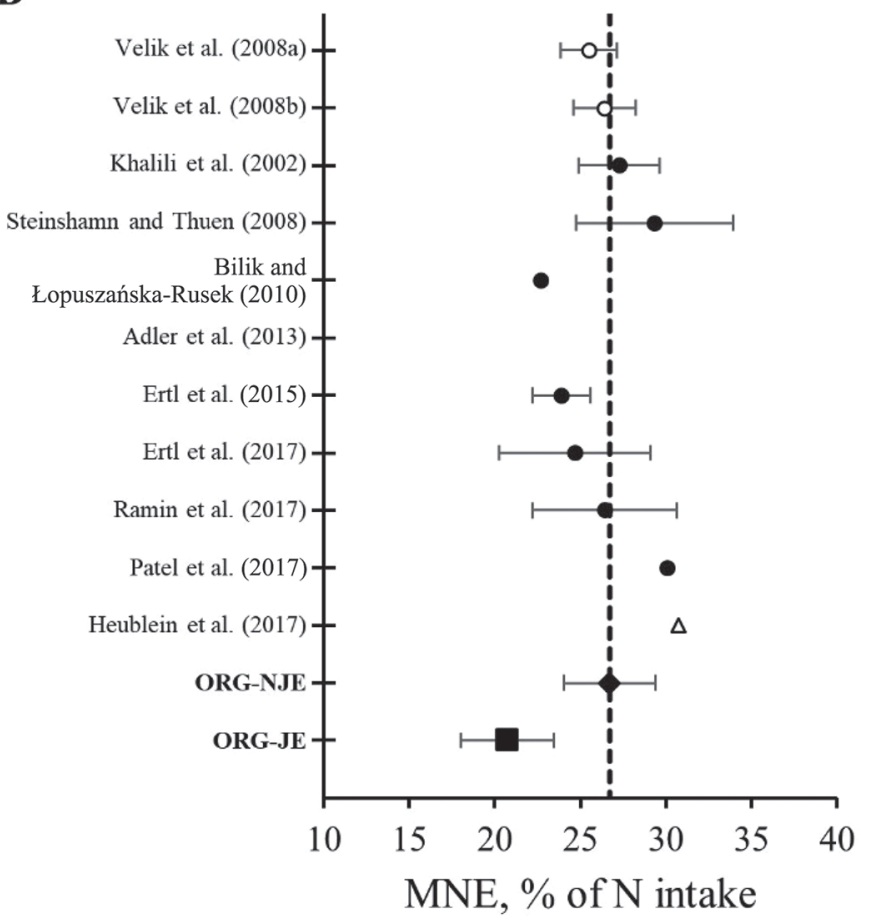

D

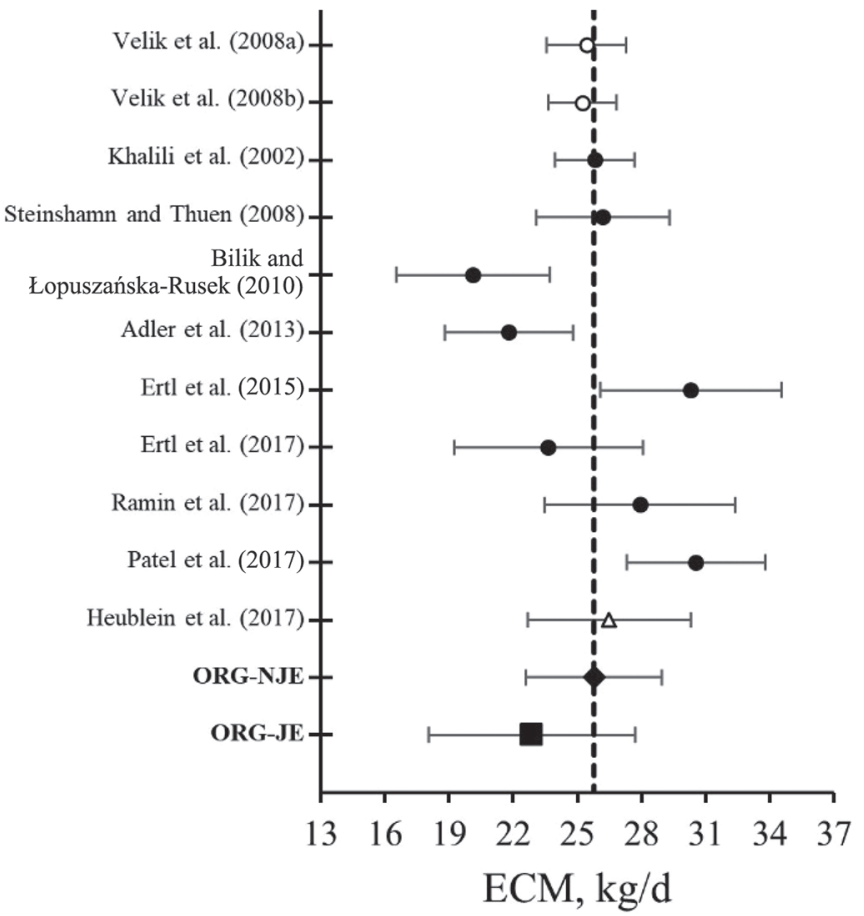

Figure 2. (A) Feed efficiency (FE; calculated as ECM yield/DMI), (B) milk N efficiency (MNE; calculated as milk $\mathrm{N}$ yield/N intake $\times 100$ ), (C) DMI, and (D) ECM yield of individual study means used in the organic non-Jersey cow data set (ORG-NJE) and the overall studies mean of experiments included in the organic Jersey cow data set (ORG-JE). Open circle $(\bigcirc)$, filled circle $(\bullet)$, and triangle $(\Delta)$ represent studies in which cows were fed corn silage, grass or legume hay or silage, and grazed herbage, respectively. Diamond $(\checkmark)$ represents the overall mean from the 11 studies belonging to the ORG-NJE data set, and square (ם) represents the overall mean from the 11 studies of the ORG-JE data set. Error bars indicate SD reported or calculated from SEM of individual studies. See Appendix 1 for references. 
settings), dietary $\mathrm{F}: \mathrm{C}$, proportion of herbage in the diet $\mathrm{DM}$, and grain sources may explain the poorer FE estimated from Hardie et al. (2014) compared with the ORG-JE and ORG-NJE data sets.

According to previous studies (McBride and Greene, 2009; Pereira et al., 2013; Stiglbauer et al., 2013; Hardie et al., 2014; Hafla et al., 2018) and the current review data sets, limited inclusion of corn silage $(\sim \leq 15 \%$ of the diet DM) and heavy reliance on forages appear to be the chief determinants for the low to moderate FE observed for organic dairy cows. It is well known that growing corn for organic silage production is challenged by weed pressure and the development of a balanced, cost-effective fertility plan (Roth, 2010). Bootstrap replications revealed that diets containing corn silage plus concentrate had the greatest feed costs in New Hampshire and Maine (Marston et al., 2011). In contrast, herbage is the cheapest feed source in organic dairies, and USDA National Organic Program regulations mandate that at least $30 \%$ of the diet DM must be consumed from pasture for a minimum of $120 \mathrm{~d}$ during the grazing season (USDA NOP, 2010). Therefore, well-managed intensive rotational grazing systems and pasture renovation to elevate the proportion of legumes available for grazing are key strategies to improve forage nutritive value (Rayburn and Fox, 1991; Undersander et al., 2014; Johansen et al., 2017) as well as FE and MNE. In addition, annual forage crops such as brown midrib 6 dwarf forage sorghum, oat, wheat, and triticale can be attractive options to augment forage yield and silage production in dairy farms (Harper et al., 2017a,b). Further, Japanese millet and brown midrib sorghum $\times$ sudangrass can replace cool-season perennial grass herbage (Dillard et al., 2017; Ruh et al., 2018), and brassicas are suitable to extend the fall grazing season while providing exceptional forage quality (Dillard et al., 2018). Diurnal cutting or grazing management to elevate the concentration of NSC in forages should also be considered for improving forage nutritive value and animal performance. For instance, alfalfa cut in the afternoon and harvested as baleage improved DMI, yields of milk and milk components, MNE, and microbial protein synthesis in Holstein cows fed forage-only diets (Brito et al., 2008, 2009). Gregorini et al. (2006) showed that beef heifers allocated to pasture in the afternoon $(1500 \mathrm{~h})$ versus morning $(0700$ h) had longer and more intense grazing bouts, thus coinciding with greater forage quality and better ADG.

\section{ENTERIC $\mathrm{CH}_{4}$ EMISSIONS}

There are limited $\mathrm{CH}_{4}$ emission data from controlled feeding trials done with organic dairy cows regardless of breed type as well as from experiments using Jersey cows under conventional management. Therefore, comparisons and inferences regarding enteric $\mathrm{CH}_{4}$ emissions in this symposium review are constrained by the lack of robust data. A detailed description of the experimental design and treatments used in the ORG-JE $\mathrm{CH}_{4}$ data set is presented in Supplemental Table S1 (https://doi .org/10.3168/jds.2019-17232). Enteric $\mathrm{CH}_{4}$ production, $\mathrm{CH}_{4}$ yield, and $\mathrm{CH}_{4}$ intensity from 5 studies included in the ORG-JE $\mathrm{CH}_{4}$ data set averaged $348 \mathrm{~g} / \mathrm{d}, 19 \mathrm{~g} / \mathrm{kg}$ of DMI, and $15.7 \mathrm{~g} / \mathrm{kg}$ of ECM, respectively (Table 2). Data from 4 experiments that were part of the CON-JE $\mathrm{CH}_{4}$ data set resulted in $\mathrm{CH}_{4}$ production (mean $=264$ $\mathrm{g} / \mathrm{d}), \mathrm{CH}_{4}$ yield $\left(\right.$ mean $=16.1 \mathrm{~g} / \mathrm{kg}$ of DMI), and $\mathrm{CH}_{4}$ intensity $($ mean $=9.18 \mathrm{~g} / \mathrm{kg}$ of $\mathrm{ECM}$ ) values that were 24.1, 15.3, and $41.5 \%$ lower, respectively, than those observed for cows in the ORG-JE $\mathrm{CH}_{4}$ data set (Table 2 ). Decreased enteric $\mathrm{CH}_{4}$ emissions in the CON-JE $\mathrm{CH}_{4}$ data set were not surprising and likely explained by greater ECM yield $(+25.9 \%)$, lower dietary F:C, and inclusion of corn silage (up to $40.5 \%$ of the diet DM) compared with the ORG-JE $\mathrm{CH}_{4}$ data set. In addition, supplements such as blood meal, tallow, lard, and rumen-protected AA, which are not allowed in organic dairy agriculture, were used in studies belonging to the CON-JE $\mathrm{CH}_{4}$ data set, thus resulting in diets that better match animals' nutrient requirements.

Ramin et al. (2017) reported that $\mathrm{CH}_{4}$ production, $\mathrm{CH}_{4}$ yield, and $\mathrm{CH}_{4}$ intensity averaged $395 \mathrm{~g} / \mathrm{d}, 21.2 \mathrm{~g} /$ $\mathrm{kg}$ of DMI, and $16 \mathrm{~g} / \mathrm{kg}$ of ECM, respectively, in organic Swedish Red cows consuming grass silage supplemented with barley or various legume seeds (i.e., expelled rapeseed, peas, untreated field beans, or heat-treated field beans). These $\mathrm{CH}_{4}$ emission values are relatively close to those observed for cows in the ORG-JE $\mathrm{CH}_{4}$ data set, possibly because DMI and ECM yield were similar among studies despite the large difference in body size between Swedish Red and Jersey cows. Using the intercontinental $\mathrm{CH}_{4}$ prediction equation $\left(\mathrm{CH}_{4}, \mathrm{~g} / \mathrm{d}=\right.$ $124+13.3 \times$ DMI) of Niu et al. (2018) and the DMI prediction equation of NRC (2001) to estimate enteric $\mathrm{CH}_{4}$ production from Hardie et al. (2014) resulted in $378,330,379$, and $339 \mathrm{~g}$ of $\mathrm{CH}_{4} / \mathrm{d}$ for cows in clusters $1,2,3$, and 4 , respectively. Organic dairies in cluster 2 , which were characterized as the lowest input systems, had cows with the poorest estimated $\mathrm{CH}_{4}$ intensity (24 $\mathrm{g} / \mathrm{kg}$ of ECM) followed by those in clusters $4(17.3 \mathrm{~g} /$ $\mathrm{kg}$ of ECM), $1(15.8 \mathrm{~g} / \mathrm{kg}$ of ECM $)$, and $3(14.7 \mathrm{~g} / \mathrm{kg}$ of ECM). Clusters 1 and 3, which differed in herd size, fed diets formulated with a greater variety of feeds and lower F:C than farms in clusters 2 and 4 . Cluster 2 dairies differed from farms in cluster 4 by not feeding corn silage or haylage and using $100 \%$ of the land base for grazing. Estimated $\mathrm{CH}_{4}$ intensity of clusters 1, 2, 3, and 4 was $17,77.7,8.9$, and $28.1 \%$ greater, respectively, 
than that $($ mean $=13.5 \mathrm{~g} / \mathrm{kg}$ of $\mathrm{ECM})$ in an intercontinental data set populated mostly by conventional Holstein data (Niu et al., 2018). It is important to emphasize that these comparisons should be interpreted cautiously because both $\mathrm{DMI}$ and $\mathrm{CH}_{4}$ production from Hardie et al. (2014) were obtained through prediction equations. Nevertheless, this exercise revealed a wide range in $\mathrm{CH}_{4}$ intensity across Wisconsin organic dairies due to different nutritional and management strategies. Producing high-quality forage while improving grazing management is paramount to increase ECM yield and reduce $\mathrm{CH}_{4}$ intensity, particularly for farms in clusters 2 and 4 that rely more heavily on forage sources. In fact, feeding high-quality perennial ryegrass herbage to dairy cows decreased both $\mathrm{CH}_{4}$ yield $(-10.9 \%)$ and $\mathrm{CH}_{4}$ intensity ( $\left.-13 \%\right)$ compared with TMR (O'Neill et al., 2011). Muñoz et al. (2016) observed reduced $\mathrm{CH}_{4}$ yield $(-8.2 \%)$ and a tendency for lowered $\mathrm{CH}_{4}$ intensity $(-10.1 \%)$ in grazing dairy cows offered low $(2,200 \mathrm{~kg}$ of DM/ha) versus high $(5,000 \mathrm{~kg}$ of $\mathrm{DM} / \mathrm{ha})$ pregrazing herbage mass due to improved forage nutritive value with the low herbage mass.

\section{ORGANIC GRASS-FED MILK PRODUCTION}

Demand for "grass-fed" dairy products has been increasing in the United States, largely due to consumers' perception of improved health outcomes from intake of n-3 fatty acids (Benbrook et al., 2018) as well as perceived benefits to the environment and animal welfare (von Keyserlingk et al., 2013, 2017; Schuppli et al., 2014). Currently, the grass-fed market is the only growing sector of the organic dairy industry in the United States, and farmers generally are paid additional premiums to meet demand. For shipping grass-fed milk, farmers must rely exclusively on pasture and conserved feeds, except corn silage, to feed their cows. Supplementation with minerals and energy supplements that do not contain grain or grain by-products typically is allowed. Therefore, sugarcane molasses (dried and liquid) has been used by some grass-fed farmers, and alternative options such as sucrose and vegetable by-products, particularly sugar beets, are being considered. According to Brito et al. (2017), yields of milk, milk fat, and true protein did not differ in organic Jersey cows grazing cool-season herbage supplemented with ground corn or liquid molasses as the sole energy source. These results revealed that liquid molasses can replace ground corn, but costs, animal health, and BCS would determine the amount of molasses fed (Brito et al., 2017). Liquid molasses also reduced the concentrations of MUN and plasma urea $\mathrm{N}$, suggesting improved $\mathrm{N}$ utilization (Brito et al., 2017). An ongoing study using grass-fed dairies in the northeastern United States showed that MUN concentrations averaged $12.1 \mathrm{mg} / \mathrm{dL}$ in 2017 and $12.4 \mathrm{mg} / \mathrm{dL}$ in 2018 and ranged from 5.3 to $23.8 \mathrm{mg} /$ dL (Heather Darby, University of Vermont Extension, St. Albans, VT; personal communication). This wide range in MUN implies a large variation in feeding management strategies across northeastern grass-fed

Table 2. Descriptive statistics for variables belonging to 2 enteric methane $\left(\mathrm{CH}_{4}\right)$ data sets used to compare organic versus conventional Jersey cows using study means

\begin{tabular}{|c|c|c|c|c|c|}
\hline Item & No. ${ }^{1}$ & Mean & $\mathrm{SD}$ & Minimum & Maximum \\
\hline \multicolumn{6}{|c|}{ Studies with organic Jersey cows ${ }^{2}$} \\
\hline $\mathrm{BW}, \mathrm{kg}$ & 5 & 444 & 32.4 & 412 & 482 \\
\hline DIM & 5 & 122 & 26.3 & 102 & 159 \\
\hline DMI, $\mathrm{kg} / \mathrm{d}$ & 5 & 18.0 & 1.88 & 16.4 & 20.4 \\
\hline ECM yield, kg/d & 5 & 23.2 & 5.75 & 15.1 & 29.5 \\
\hline $\mathrm{CH}_{4}$ production, $\mathrm{g} / \mathrm{d}$ & 5 & 348 & 57.2 & 272 & 407 \\
\hline $\mathrm{CH}_{4}$ yield, $\mathrm{g} / \mathrm{kg}$ of $\mathrm{DMI}$ & 5 & 19.0 & 1.58 & 16.6 & 20.7 \\
\hline $\mathrm{CH}_{4}$ intensity, $\mathrm{g} / \mathrm{kg}$ of ECM & 5 & 15.7 & 5.03 & 11.3 & 24.3 \\
\hline Forage, $\%$ of diet DM & 5 & 63.5 & 3.73 & 60.0 & 70.0 \\
\hline Corn silage, \% of diet DM & - & - & - & - & - \\
\hline \multicolumn{6}{|c|}{ Studies with conventional Jersey cows ${ }^{3}$} \\
\hline $\mathrm{BW}, \mathrm{kg}$ & 4 & 468 & 20.5 & 442 & 486 \\
\hline DIM & 4 & 182 & 115 & 79.9 & 325 \\
\hline DMI, kg/d & 4 & 16.5 & 0.88 & 15.4 & 17.4 \\
\hline ECM yield, kg/d & 4 & 29.2 & 3.95 & 23.9 & 33.4 \\
\hline $\mathrm{CH}_{4}$ production, $\mathrm{g} / \mathrm{d}$ & 4 & 264 & 20.3 & 244 & 288 \\
\hline $\mathrm{CH}_{4}$ yield, $\mathrm{g} / \mathrm{kg}$ of $\mathrm{DMI}$ & 4 & 16.1 & 1.40 & 14.0 & 17.1 \\
\hline $\mathrm{CH}_{4}$ intensity, $\mathrm{g} / \mathrm{kg}$ of $\mathrm{ECM}$ & 4 & 9.18 & 1.39 & 7.31 & 10.5 \\
\hline Forage, $\%$ of diet DM & 4 & 52.2 & 49.6 & 55.0 & 2.77 \\
\hline Corn silage, $\%$ of diet DM & 4 & 32.6 & 24.7 & 40.5 & 7.68 \\
\hline
\end{tabular}

${ }^{1}$ Number of studies.

${ }^{2}$ Conducted at the University of New Hampshire Burley-Demeritt Organic Dairy Research Farm (Lee, NH).

${ }^{3}$ Conducted at the University of Nebraska (Lincoln). 
Brito and Silva: PRODUCTION, MANAGEMENT, AND THE ENVIRONMENT SYMPOSIUM: PROFITABILITY AND SUSTAINABILITY 5735

dairy farms, such as the proportion of herbage in the diet DM, use of molasses or alternative energy sources, sward botanical composition (high vs. low proportion of legumes), and forage nutritive value.

Flack (2016) reported that milk yield in grass-fed dairies from the northeastern United States ranged from 2,177 to $4,990 \mathrm{~kg} / \mathrm{cow}$ yearly, with most farms producing between 2,948 and 3,629 kg/cow. Successful grass-fed dairies have been producing milk in the higher end of the spectrum for several years, thus avoiding cash flow issues to cover farm overhead costs and increased forage and land needs (Flack, 2016). These successful farms also have been able to maximize DMI of forages through genetic selection of animals that perform well in their dairies in addition to producing high-quality forages and delivering best grazing management (Flack, 2016).

\section{FUTURE PERSPECTIVES}

It is conceivable that, at least in the short term, more organic farms will make the transition from traditional to grass-fed practices to keep up with the growing demand for grass-fed milk and dairy products and to reduce feed costs. However, research on nutrition, genetics, and whole-farm systems is needed to guide farmers' decisions on how to best feed and breed to optimize forage DMI and milk production while reducing the environmental impact of organic dairies. Liang et al. (2017), using the integrated farm systems model (Rotz, 2013), showed that greenhouse gas emissions per tonne of ECM, with or without accounting for soil carbon change, were greatest in organic dairy farms belonging to cluster 2 followed by clusters 4,1 , and 3 . Their whole-farm modeling simulations indicated that more greenhouse gas was emitted into the environment the longer the cows had access to pasture during the grazing season (Liang et al., 2017). Grass-fed organic dairies use nutritional and management strategies that resemble those adopted by farms in cluster 2 (Hardie et al., 2014; Liang et al., 2017) except the lack of concentrate. Thus, it is conceivable that whole-farm greenhouse gas emissions could be greater in grass-fed dairies than in farms from cluster 2. As discussed earlier, the economic and environmental implications of grass-fed dairy practices deserve future investigations.

It is well established that consolidation in the conventional dairy sector over the past decades in the United States led to fewer farms and larger herd sizes (McDonald et al., 2007; Winsten et al., 2010; Holly et al., 2019). Organic dairies are characterized by small herd sizes (<100 lactating cows/farm), particularly in the Northeast, Midwest, and Corn Belt regions of the United States, and few larger herds (>100 lactating cows), located mostly in the West (McBride and Greene, 2009; Pereira et al., 2013; Stiglbauer et al., 2013; Hardie et al., 2014). However, there are signs of consolidation in the organic dairy segment as well. For instance, despite there being only 6 organic dairy operations in Texas (USDA NASS, 2017), it has the second largest number of dairy cows and organic milk sales, only behind California (USDA NASS, 2017). The effect of large organic dairy farms and early signs of consolidation on present and future economic viability of the whole industry is unfolding, but decreased payment prices currently seen are undeniably linked to oversupply of organic milk. As in the conventional dairy sector, larger organic dairy herds may benefit from economy of scales, which appear to be the driving force for consolidation.

\section{CONCLUSIONS}

The FE and MNE data presented in this symposium review should be interpreted cautiously because comparisons between organic and conventional dairy systems were performed using study means and relatively small data sets. It was beyond the scope of this review to conduct a meta-analysis due to the lack of robust data from controlled feeding trials using organic-certified dairy cows. Further, organic and conventional dairy farms in the United States adopt distinct management and feeding strategies, most notably mandatory access to pasture and the outdoors if under organic regulation, and efficiency comparisons between both systems should not neglect these inherent differences. Regardless of comparisons, organic and conventional farmers should strive to improve FE and MNE because it may reduce the environmental impact of dairy systems. Nevertheless, our critical review demonstrated that organic Jersey cows had lower FE and MNE than conventional Jersey cows, whereas non-Jersey organic dairy breeds fell in between. It is important to consider that reduced FE in organic Jersey cows does not necessarily imply less profitability due to greater milk prices compared with the conventional sector. Methane intensity $(\mathrm{g} / \mathrm{kg}$ of ECM) increased when comparing organic versus conventional Jersey cows, suggesting that enhanced supply of fermentable energy by including corn silage in organic dairy diets may be a viable strategy to dilute enteric $\mathrm{CH}_{4}$ emissions via improved ECM. The rapidly growing organic "grass-fed" milk market provides farmers with opportunities to capitalize on additional premiums, but further research is needed to better characterize these dairies to maximize profitability and efficiency (FE and MNE) while reducing their carbon footprint. Early signs of consolidation of organic dairy agriculture in the United States are especially concerning for small and mid-size operations because they cannot compete 
Brito and Silva: PRODUCTION, MANAGEMENT, AND THE ENVIRONMENT SYMPOSIUM: PROFITABILITY AND SUSTAINABILITY 5736

on economies of scale. Future research to improve yields and economic viability of organic corn silage production is warranted.

\section{ACKNOWLEDGMENTS}

The authors thank the New Hampshire Agricultural Experiment Station for the overall research support (Scientific Contribution Number 2839). This invited symposium review paper is a product of the USDA National Institute of Food and Agriculture (NIFA; Washington, DC) Hatch Multistate NC-2042 project. The authors have not stated any conflicts of interest.

\section{REFERENCES}

Aikman, P. C., C. K. Reynolds, and D. E. Beever. 2008. Diet digestibility, rate of passage, and eating and rumination behavior of Jersey and Holstein cows. J. Dairy Sci. 91:1103-1114. https://doi .org/10.3168/jds.2007-0724.

Antaya, N. T., M. Ghelichkhan, A. B. D. Pereira, K. J. Soder, and A. F. Brito. 2019. Production, milk iodine, and nutrient utilization in Jersey cows supplemented with the brown seaweed Ascophyllum nodosum (kelp meal) during the grazing season. J. Dairy Sci. 102:8040-8058. https://doi.org/10.3168/jds.2019-16478.

Benbrook, C. M., D. R. Davis, B. J. Heins, M. A. Latif, C. Leifert, L. Peterman, G. Butler, O. Faergeman, S. Abel-Caines, and M. Baranski. 2018. Enhancing the fatty acid profile of milk through forage-based rations, with nutrition modeling of diet outcomes. Food Sci. Nutr. 6:681-700. https://doi.org/10.1002/fsn3.610.

Brito, A. F., K. J. Soder, P. Y. Chouinard, S. F. Reis, S. Ross, M. D. Rubano, and M. D. Casler. 2017. Production performance and milk fatty acid profile in grazing dairy cows offered ground corn or liquid molasses as the sole supplemental nonstructural carbohydrate source. J. Dairy Sci. 100:8146-8160. https://doi.org/10 $.3168 /$ jds.2017-12618.

Brito, A. F., G. F. Tremblay, A. Bertrand, Y. Castonguay, G. Bélanger, R. Michaud, H. Lapierre, C. Benchaar, H. V. Petit, D. R. Ouellet, and R. Berthiaume. 2008. Alfalfa cut at sundown and harvested as baleage improves milk yield of late-lactation dairy cows. J. Dairy Sci. 91:3968-3982. https://doi.org/10.3168/jds.2008 $-1282$.

Brito, A. F., G. F. Tremblay, H. Lapierre, A. Bertrand, Y. Castonguay, G. Bélanger, R. Michaud, C. Benchaar, D. R. Ouellet, and R. Berthiaume. 2009. Alfalfa cut at sundown and harvested as baleage increases bacterial protein synthesis in late-lactation dairy cows. J. Dairy Sci. 92:1092-1107. https://doi.org/10.3168/jds.2008 -1469 .

Dailey, C. A., B. J. Heins, K. J. Soder, U. Sorge, A. F. Brito, K. A. E. Mullen, and S. P. Washburn. 2017. Organic dairy production systems. Pages 115-126 in Large Dairy Herd Management. 3rd ed. D. K. Beede, ed. American Dairy Science Association, Champaign, IL.

Dalton, T. J., R. Parsons, R. Kersbergen, G. Rogers, D. Kaupilla, L. McCrory, L. A. Bragg, and Q. Wang. 2008. A comparative analysis of organic dairy farms in Maine and Vermont: Farm financial information from 2004 to 2006. Bulletin 851. Accessed Jul. 1, 2019. https://digitalcommons.library.umaine.edu/aes_bulletin/3/.

de Ondarza, M. B., and J. M. Tricarico. 2017. Review: Advantages and limitations of dairy efficiency measures and the effects of nutrition and feeding management interventions. Prof. Anim. Sci. 33:393-400. https://doi.org/10.15232/pas.2017-01624.

Dillard, S. L., A. N. Hafla, A. I. Roca-Fernández, A. F. Brito, M. D. Rubano, and K. J. Soder. 2017. Effect of feeding warm-season annuals with orchardgrass on ruminal fermentation and methane output in continuous culture. J. Dairy Sci. 100:1179-1188. https:/ /doi.org/10.3168/jds.2016-11510.

Dillard, S. L., A. I. Roca-Fernández, M. D. Rubano, K. R. Elkin, and K. J. Soder. 2018. Enteric methane production and ruminal fermentation of forage brassica diets fed in continuous culture. J. Anim. Sci. 96:1362-1374. https://doi.org/10.1093/jas/sky030.

Dorich, C. D., R. K. Varner, A. B. D. Pereira, R. Martineau, K. J. Soder, and A. F. Brito. 2015. Short communication: Use of a portable, automated, open-circuit gas quantification system and the sulfur hexafluoride tracer technique for measuring enteric methane emissions in Holstein cows fed ad libitum or restricted. J. Dairy Sci. 98:2676-2681. https://doi.org/10.3168/jds.2014-8348.

Drehmel, O. R., T. M. Brown-Brandl, J. V. Judy, S. C. Fernando, P. S. Miller, K. E. Hales, and P. J. Kononoff. 2018. The influence of fat and hemicellulose on methane production and energy utilization in lactating Jersey cattle. J. Dairy Sci. 101:7892-7906. https://doi .org/10.3168/jds.2017-13822.

Flack, S. 2016. 100 percent grassfed. Pages 138-144 in The Art and Science of Grazing: How Grass Farmers Can Create Sustainable Systems for Healthy Animals and Farm Ecosystems. L. Jorstad, ed. Chelsea Green Publishing, White River Junction, VT.

Foth, A. J., T. Brown-Brandl, K. J. Hanford, P. S. Miller, G. Garcia Gomez, and P. J. Kononoff. 2015. Energy content of reduced-fat dried distillers grains with solubles for lactating dairy cows. J. Dairy Sci. 98:7142-7152. https://doi.org/10.3168/jds.2014-9226.

Freetly, H. C., J. A. Nienaber, and T. Brown-Brandl. 2006. Partitioning of energy during lactation of primiparous beef cows. J. Anim. Sci. 84:2157-2162. https://doi.org/10.2527/jas.2005-534.

Gregorini, P., M. Eirin, R. Refi, M. Ursino, O. E. Ansin, and S. A. Gunter. 2006. Timing of herbage allocation in strip grazing: Effects on grazing pattern and performance of beef heifers. J. Anim. Sci. 84:1943-1950. https://doi.org/10.2527/jas.2005-537.

Gunter, S. A., and M. R. Beck. 2018. Measuring the respiratory gas exchange by grazing cattle using an automated, open-circuit gas quantification system. Transl. Anim. Sci. 2:11-18. https://doi.org/ $10.1093 / \operatorname{tas} / \operatorname{txx} 009$.

Hafla, A. N., K. J. Soder, A. F. Brito, R. Kersbergen, A. F. Benson, H. Darby, M. D. Rubano, S. L. Dillard, J. Kraft, and S. F. Reis. 2018. Effects of seasonal variation and winter supplementation of ground whole flaxseed on milk fatty acid composition of dairy cows in organic farms in the northeastern United States. Prof. Anim. Sci. 34:397-409. https://doi.org/10.15232/pas.2018-01755.

Hammond, K. J., D. J. Humphries, L. A. Crompton, C. Green, and C. K. Reynolds. 2015. Methane emissions from cattle: Estimates from short-term measurements using a GreenFeed system compared with measurements obtained using respiration chambers or sulphur hexafluoride tracer. Anim. Feed Sci. Technol. 203:41-52. https://doi.org/10.1016/j.anifeedsci.2015.02.008.

Hardie, C. A., M. Wattiaux, M. Dutreuil, R. Gildersleeve, N. S. Keuler, and V. E. Cabrera. 2014. Feeding strategies on certified organic dairy farms in Wisconsin and their effect on milk production and income over feed costs. J. Dairy Sci. 97:4612-4623. https://doi .org/10.3168/jds.2013-7763.

Harper, M. T., J. Oh, F. Giallongo, J. C. Lopes, G. W. Roth, and A. N. Hristov. 2017a. Using brown midrib 6 dwarf forage sorghum silage and fall-grown oat silage in lactating dairy cow rations. J. Dairy Sci. 100:5250-5265. https://doi.org/10.3168/jds.2017-12552.

Harper, M. T., J. Oh, F. Giallongo, G. W. Roth, and A. N. Hristov. $2017 \mathrm{~b}$. Inclusion of wheat and triticale silage in the diet of lactating dairy cows. J. Dairy Sci. 100:6151-6163. https://doi.org/10 $.3168 /$ jds.2017-12553.

Heinrichs, A. J., and V. A. Ishler. 2016. Feed efficiency in lactating cows and relationship to income over feed costs. Accessed Sep. 21, 2019. https://extension.psu.edu/feed-efficiency-in-lactating-cows -and-relationship-to-income-over-feed-costs.

Holly, M. A., K. M. Gunn, C. A. Rotz, and P. J. A. Kleinman. 2019 Management characteristics of Pennsylvania dairy farms. Appl. Anim. Sci. 35:325-338. https://doi.org/10.15232/aas.2018-01833.

Isenberg, B. J., K. J. Soder, A. B. D. Pereira, R. Standish, and A. F. Brito. 2019. Production, milk fatty acid profile, and nutrient utili- 
zation in grazing dairy cows supplemented with ground flaxseed. J. Dairy Sci. 102:1294-1311. https://doi.org/10.3168/jds.2018-15376.

Johansen, M., P. Lund, and M. R. Weisbjerg. 2017. Feed intake and milk production in dairy cows fed different grass and legume species: A meta-analysis. Animal 12:66-75. https://doi.org/10.1017/ S1751731117001215.

Johnson, K., M. Huyler, H. Westberg, B. Lamb, and P. Zimmerman. 1994. Measurement of methane emissions from ruminant livestock using a sulfur hexafluoride tracer technique. Environ. Sci. Technol. 28:359-362. https://doi.org/10.1021/es00051a025.

Judy, J. V., G. C. Bachman, T. M. Brown-Brandl, S. C. Fernando, K. E. Hales, K. J. Harvatine, P. S. Miller, and P. J. Kononoff. 2019. Increasing the concentration of linolenic acid in diets fed to Jersey cows in late lactation does not affect methane production. J. Dairy Sci. 102:2085-2093. https://doi.org/10.3168/jds.2018-14608.

Judy, J. V., G. C. Bachman, T. M. Brown-Brandl, S. C. Fernando, K. E. Hales, P. S. Miller, R. R. Stowell, and P. J. Kononoff. 2018. Energy balance and diurnal variation in methane production as affected by feeding frequency in Jersey cows in late lactation. J. Dairy Sci. 101:10899-10910. https://doi.org/10.3168/jds.2018 $-14596$.

Kauffman, A. J., and N. R. St-Pierre. 2001. The relationship of milk urea nitrogen to urine nitrogen excretion in Holstein and Jersey cows. J. Dairy Sci. 84:2284-2294. https://doi.org/10.3168/jds .S0022-0302(01)74675-9.

Kaufmann, L. D., A. Münger, M. Rérat, P. Junghans, S. Görs, C. C. Metges, and F. Dohme-Meier. 2011. Energy expenditure of grazing cows and cows fed grass indoors as determined by the $13 \mathrm{C}$ bicarbonate dilution technique using an automatic blood sampling system. J. Dairy Sci. 94:1989-2000. https://doi.org/10.3168/jds $.2010-3658$.

Kidane, A., M. Øverland, L. T. Mydland, and E. Prestløkken. 2018. Interaction between feed use efficiency and level of dietary crude protein on enteric methane emission and apparent nitrogen use efficiency with Norwegian Red dairy cows. J. Anim. Sci. 96:39673982. https://doi.org/10.1093/jas/sky256.

Knapp, J. R., G. L. Laur, P. A. Vadas, W. P. Weiss, and J. M. Tricarico. 2014. Invited review: Enteric methane in dairy cattle production: Quantifying the opportunities and impact of reducing emissions. J. Dairy Sci. 97:3231-3261. https://doi.org/10.3168/jds .2013-7234.

Liang, D., F. Sun, M. A. Wattiaux, V. E. Cabrera, J. L. Hedtcke, and E. M. Silva. 2017. Effect of feeding strategies and cropping systems on greenhouse gas emission from Wisconsin certified organic dairy farms. J. Dairy Sci. 100:5957-5973. https://doi.org/10.3168/ jds.2016-11909.

Marston, S. P., G. W. Clark, G. W. Anderson, R. J. Kersbergen, M. Lunak, D. P. Marcinkowski, M. R. Murphy, C. G. Schwab, and P. S. Erickson. 2011. Maximizing profit on New England organic dairy farms: An economic comparison of 4 total mixed rations for organic Holsteins and Jerseys. J. Dairy Sci. 94:3184-3201. https:/ /doi.org/10.3168/jds.2010-3778.

McBride, W. D., and C. Greene. 2009. Characteristics, costs, and issues for organic dairy farming. Economic Research Report No. 82. USDA Economic Research Service, Washington, DC. Accessed Jul. 2, 2019. https://naldc.nal.usda.gov/download/35889/PDF.

McDonald, J. M., E. J. O’Donoghue, W. D. McBride, R. F. Nehring, C. L. Sandretto, and R. Mosheim. 2007. Profits, costs, and the changing structure of dairy farming. Economic Research Report No. 47. USDA Economic Research Service, Washington, DC. Accessed Jun. 25, 2019. https://www.ers.usda.gov/webdocs/publications 45868/17032_err47fm_1_.pdf?v=41746.

Muñoz, C., P. A. Letelier, E. M. Ungerfeld, J. M. Morales, S. Hube, and L. A. Pérez-Prieto. 2016. Effects of pregrazing herbage mass in late spring on enteric methane emissions, dry matter intake, and milk production of dairy cows. J. Dairy Sci. 99:7945-7955. https:/ /doi.org/10.3168/jds.2016-10919.

Niu, M., E. Kebreab, A. N. Hristov, J. Oh, C. Arndt, A. Bannink, A. R. Bayat, A. F. Brito, T. Boland, D. Casper, L. A. Crompton, J. Dijkstra, M. A. Eugène, P. C. Garnsworthy, M. N. Haque, A. L. F. Hellwing, P. Huhtanen, M. Kreuzer, B. Kuhla, P. Lund, J.
Madsen, C. Martin, S. C. McClelland, M. McGee, P. J. Moate, S. Muetzel, C. Muñoz, P. O'Kiely, N. Peiren, C. K. Reynolds, A. Schwarm, K. J. Shingfield, T. M. Storlien, M. R. Weisbjerg, D. R. Yáñez-Ruiz, and Z. Yu. 2018. Prediction of enteric methane production, yield, and intensity in dairy cattle using an intercontinental database. Glob. Chang. Biol. 24:3368-3389. https://doi .org/10.1111/gcb.14094.

NRC. 2001. Nutrient Requirements of Dairy Cattle. 7th rev. ed. Natl. Acad. Sci., Washington, DC.

O'Hara, J. K., and R. L. Parsons. 2013. The economic value of organic dairy farms in Vermont and Minnesota. J. Dairy Sci. 96:61176126. https://doi.org/10.3168/jds.2013-6662.

O'Neill, B. F., M. H. Deighton, B. M. O'Loughlin, F. J. Mulligan, T. M. Boland, M. O'Donovan, and E. Lewis. 2011. Effects of a perennial ryegrass diet or total mixed ration diet offered to springcalving Holstein-Friesian dairy cows on methane emissions, dry matter intake, and milk production. J. Dairy Sci. 94:1941-1951. https://doi.org/10.3168/jds.2010-3361.

Orth, R. 1992. Sample day and lactation report. DHIA 200 Fact Sheet A-2. Mid-States DRPC, Ames, IA.

Pereira, A. B. D., A. F. Brito, L. L. Townson, and D. H. Townson. 2013. Assessing the research and education needs of the organic dairy industry in the northeastern United States. J. Dairy Sci. 96:7340-7348. https://doi.org/10.3168/jds.2013-6690.

Pereira, A. B. D., S. A. Utsumi, C. D. Dorich, and A. F. Brito. 2015 Integrating spot short-term measurements of carbon emissions and backward dietary energy partition calculations to estimate intake in lactating dairy cows fed ad libitum or restricted. J. Dairy Sci. 98:8913-8925. https://doi.org/10.3168/jds.2015-9659.

Ramin, M., A. Höjer, and M. Hetta. 2017. The effects of legume seeds on the lactation performance of dairy cows fed grass silage-based diets. Agric. Food Sci. 26:129-137. https://doi.org/10.23986/afsci .64417 .

Rayburn, E. B., and D. F. Fox. 1991. Forage quality of intensive rotationally grazed pastures. Cornell Cooperative Extension Animal Science Mimeograph Series No. 151. Cornell University, Ithaca, NY.

Resende, T. L., J. Kraft, K. J. Soder, A. B. D. Pereira, D. E. Woitschach, R. B. Reis, and A. F. Brito. 2015. Incremental amounts of ground flaxseed decrease milk yield but increase n-3 fatty acids and conjugated linoleic acids in dairy cows fed high-forage diets. J. Dairy Sci. 98:4785-4799. https://doi.org/10.3168/jds.2014-9115.

Reynolds, M. A., T. M. Brown-Brandl, J. V. Judy, K. J. Herrick, K. E. Hales, A. K. Watson, and P. J. Kononoff. 2019. Use of indirect calorimetry to evaluate utilization of energy in lactating Jersey dairy cattle consuming common coproducts. J. Dairy Sci. 102:320-333. https://doi.org/10.3168/jds.2018-15471.

Roth, G. W. 2010. Organic corn production. Accessed Jun. 29, 2019. https://extension.psu.edu/organic-corn-production.

Rotz, C. A., M. S. Corson, D. S. Chianese, S. D. Hafner, and C. U. Coiner. 2013. The Integrated Farm System Model Manual. USDA Agricultural Research Service, Washington, DC.

Ruh, K. E., B. J. Heins, I. J. Salfer, R. D. Gardner, and M. D. Stern. 2018. Comparison of warm season and cool season forages for dairy grazing systems in continuous culture. Transl. Anim. Sci. 2:125134. https://doi.org/10.1093/tas/txy014.

Schuppli, C. A., M. A. G. von Keyserlingk, and D. M. Weary. 2014. Access to pasture for dairy cows: Responses from an online engagement. J. Anim. Sci. 92:5185-5192. https://doi.org/10.2527/ jas.2014-7725.

Stiglbauer, K. E., K. M. Cicconi-Hogan, R. Richert, Y. H. Schukken, P. L. Ruegg, and M. Gamroth. 2013. Assessment of herd management on organic and conventional dairy farms in the United States. J. Dairy Sci. 96:1290-1300. https://doi.org/10.3168/jds .2012-5845.

Undersander, D., B. Albert, D. Cosgrove, D. Johnson, and P. Peterson. 2014. Pastures for profit: A guide to rotational grazing. University of Wisconsin Extension, Madison, WI. Accessed Jun. 20, 2019. https://www.nrcs.usda.gov/Internet/FSE_DOCUMENTS/ stelprdb1097378.pdf. 
Brito and Silva: PRODUCTION, MANAGEMENT, AND THE ENVIRONMENT SYMPOSIUM: PROFITABILITY AND SUSTAINABILITY 5738

USDA NASS (USDA National Agricultural Statistics Service). 2016. Certified Organic Survey 2015 summary. Accessed Jun. 10, 2019. https://downloads.usda.library.cornell.edu/usda-esmis/files / zg64tk92g/pr76f6075/4f16c5988/OrganicProduction-09-15-2016 .pdf.

USDA NASS (USDA National Agricultural Statistics Service). 2017. Certified Organic Survey 2016 summary. Accessed May 29, 2019. https:// downloads.usda.library.cornell.edu/usda-esmis/files / zg64tk92g/70795b52w/4m90dz33q/OrganicProduction-09-20-2017 correction.pdf.

USDA NOP (USDA National Organic Program). 2010. Organic production and handling requirements. Accessed Oct. 17, 2019. https://www.ecfr.gov/cgi-bin/retrieveECFR?gp=\&SID = 201eac18c868e1446e394ca0231a486b\&mc $=$ true $\& n=s p 7.3 .205 . c \& r$ $=$ SUBPART\&ty $=$ HTML.

von Keyserlingk, M. A. G., A. Amorim Cestari, B. Franks, J. A. Fregonesi, and D. M. Weary. 2017. Dairy cows value access to pasture as highly as fresh feed. Sci. Rep. 7:44953. https://doi.org/10.1038/ srep44953.

von Keyserlingk, M. A. G., N. P. Martin, E. Kebreab, K. F. Knowlton, R. J. Grant, M. Stephenson, C. J. Sniffen, J. P. Harner III, A. D. Wright, and S. I. Smith. 2013. Invited review: Sustainability of the US dairy industry. J. Dairy Sci. 96:5405-5425. https://doi.org/10 $.3168 /$ jds.2012-6354.

Winsten, J. R., C. D. Kerchner, A. Richardson, A. Lichau, and J. M. Hyman. 2010. Trends in the Northeast dairy industry: Large-scale modern confinement feeding and management-intensive grazing. J. Dairy Sci. 93:1759-1769. https://doi.org/10.3168/jds.2008-1831.

\section{ORCIDS}

A. F. Brito () https://orcid.org/0000-0003-3209-5473

L. H. P. Silva @ https://orcid.org/0000-0003-1447-1674

\section{Appendix 1: References Cited in Figures 1 and 2}

Adler, S. A., S. K. Jensen, E. Govasmark, and H. Steinshamn. 2013. Effect of short-term versus long-term grassland management and seasonal variation in organic and conventional dairy farming on the composition of bulk tank milk. J. Dairy Sci. 96:5793-5810. 10.3168/jds.2012-5765.

Aikman, P. C., D. E. Beever, and D. J. Humphries. 2006. The effect of incremental replacement of wheat with soya hulls in diets for Jersey cows on lactational performance, diet digestibility and feeding behaviour. Livest. Sci. 104:23-32. 10.1016/j.livsci.2006.02.011.

Beecher, M., F. Buckley, S. M. Waters, T. M. Boland, D. EnriquezHidalgo, M. H. Deighton, M. O'Donovan, and E. Lewis. 2014. Gastrointestinal tract size, total-tract digestibility, and rumen microflora in different dairy cow genotypes. J. Dairy Sci. 97:3906-3917. 10.3168/jds.2013-7708.

Bilik, K., and M. L. Łopuszańska-Rusek. 2010. Effect of organic and conventional feeding of Red-and-White cows on productivity and milk composition. Ann. Anim. Sci. 10:441-458.

Drehmel, O. R., T. M. Brown-Brandl, J. V. Judy, S. C. Fernando, P. S. Miller, K. E. Hales, and P. J. Kononoff. 2018. The influence of fat and hemicellulose on methane production and energy utilization in lactating Jersey cattle. J. Dairy Sci. 101:7892-7906. 10.3168/ jds.2017-13822.

Ertl, P., Q. Zebeli, W. Zollitsch, and W. Knaus. 2015. Feeding of byproducts completely replaced cereals and pulses in dairy cows and enhanced edible feed conversion ratio. J. Dairy Sci. 98:1225-1233. 10.3168/jds.2014-8810.

Ertl, P., Q. Zebeli, W. Zollitsch, and W. Knaus. 2017. Effects of supplementation of a forage-only diet with wheat bran and sugar beet pulp in organic dairy cows. Renew. Agric. Food Syst. 32:446-453. $10.1017 /$ S1742170516000387.

Henriksen, J. C. S., L. Munksgaard, and M. R. Weisbjerg. 2018. Short-term responses in production and behavior during periods of change in concentrate allowance for dairy cows. J. Dairy Sci 101:7942-7953. 10.3168/jds.2018-14624.

Heublein, C., F. Dohme-Meier, K.-H. Südekum, R. M. Bruckmaier, S. Thanner, and F. Schori. 2017. Impact of cow strain and concentrate supplementation on grazing behaviour, milk yield and metabolic state of dairy cows in an organic pasture-based feeding system. Animal 11:1163-1173. 10.1017/S1751731116002639.

Judy, J. V., G. C. Bachman, T. M. Brown-Brandl, S. C. Fernando, K. E. Hales, K. J. Harvatine, P. S. Miller, and P. J. Kononoff. 2019. Increasing the concentration of linolenic acid in diets fed to Jersey cows in late lactation does not affect methane production. J. Dairy Sci. 102:2085-2093. https://doi.org/10.3168/jds.2018-14608.

Kauffman, A. J., and N. R. St-Pierre. 2001. The relationship of milk urea nitrogen to urine nitrogen excretion in Holstein and Jersey cows. J. Dairy Sci. 84:2284-2294. 10.3168/jds.S00220302(01)74675-9

Khalili, H., E. Kuusela, M. Suvitie, and P. Huhtanen. 2002. Effect of protein and energy supplements on milk production in organic farming. Anim. Feed Sci. Technol. 98:103-119. 10.1016/S03778401(02)00005-6.

Larsen, M. K., S. Vogdanou, A. L. F. Hellwing, I. Rybicka, and M. R. Weisbjerg. 2016. Effect of spring versus autumn grass/clover silage and rapeseed supplementation on milk production, composition and quality in Jersey cows. J. Dairy Res. 83:430-437. 10.1017/ S0022029916000595.

Meeske, R., G. D. van der Merwe, J. F. Greyling, and C. W. Cruywagen. 2002. The effect of adding an enzyme containing lactic acid bacterial inoculant to big round bale oat silage on intake, milk production and milk composition of Jersey cows. Anim. Feed Sci. Technol. 97:159-167. 10.1016/S0377-8401(01)00352-2.

Meller, R. A., B. A. Wenner, J. Ashworth, A. M. Gehman, J. Lakritz, and J. L. Firkins. 2019. Potential roles of nitrate and live yeast culture in suppressing methane emission and influencing ruminal fermentation, digestibility, and milk production in lactating Jersey cows. J. Dairy Sci. 102:6144-6156. 10.3168/jds.2018-16008.

Olijhoek, D. W.. P. Løvendahl, J. Lassen, A. L. F. Hellwing, J. K. Höglund, M. R. Weisbjerg, S. J. Noel, F. McLean, O. Højberg and P. Lund. 2018. Methane production, rumen fermentation, and diet digestibility of Holstein and Jersey dairy cows being divergent in residual feed intake and fed at 2 forage-to-concentrate ratios. J. Dairy Sci. 101:9926-9940. 10.3168/jds.2017-14278.

Patel, M., E. Wredle, E. Spörndly, and J. Bertilsson. 2017. Whole lactation production responses in high-yielding dairy cows using high-quality grass/clover silage. J. Sci. Food Agric. 97:2883-2890. 10.1002/jsfa.8119.

Prendiville, R., K. M. Pierce, and F. Buckley. 2009. An evaluation of production efficiencies among lactating Holstein-Friesian, Jersey, and Jersey $\times$ Holstein-Friesian cows at pasture. J. Dairy Sci. 92:6176-6185. 10.3168/jds.2009-2292.

Ramin, M., A. Höjer, and M. Hetta. 2017. The effects of legume seeds on the lactation performance of dairy cows fed grass silage-based diets. Agric. Food Sci. 26:129-137. 10.23986/afsci.64417.

Scheibler, R. B., J. Schafhäuser, F. A. Rizzo, J. L. Nörnberg, D. P. Vargas, J. L. S. Silva, A. C. Fluck, and V. I. Fioreze. 2015. Replacement of corn grain by brown rice grain in dairy cow rations: Nutritional and productive effects. Anim. Feed Sci. Technol. 208:214-219. 10.1016/j.anifeedsci.2015.07.013.

Steinshamn, H., and E. Thuen. 2008. White or red clover-grass silage in organic dairy milk production: Grassland productivity and milk production responses with different levels of concentrate. Livest. Sci. 119:202-215. 10.1016/j.livsci.2008.04.004.

Steyn, L., R. Meeske, and C. W. Cruywagen. 2017. The effect of dried apple pomace as a replacer for maize in the concentrate for Jersey cows grazing ryegrass pasture on production and rumen metabolism. Anim. Feed Sci. Technol. 234:264-273. 10.1016/j.anifeedsci.2017.10.011.

Steyn, L., R. Meeske, and C. W. Cruywagen. 2018. The effect of replacing maize with dried apple pomace in the concentrate on performance of Jersey cows grazing kikuyu pasture. Anim. Feed Sci. Technol. 239:85-93. 10.1016/j.anifeedsci.2018.02.012. 
van Wyngaard, J. D. V., R. Meeske, and L. J. Erasmus. 2018a. Effect of concentrate level on enteric methane emissions, production performance, and rumen fermentation of Jersey cows grazing kikuyudominant pasture during summer. J. Dairy Sci. 101:9954-9966. $10.3168 /$ jds.2017-14327.

van Wyngaard, J. D. V., R. Meeske, and L. J. Erasmus. 2018b. Effect of dietary nitrate on enteric methane emissions, production performance and rumen fermentation of dairy cows grazing kikuyu-dominant pasture during summer. Anim. Feed Sci. Technol. 244:76-87. 10.1016/j.anifeedsci.2018.08.005.

van Wyngaard, J. D. V., R. Meeske, and L. J. Erasmus. 2018c. Effect of concentrate feeding level on methane emissions, production performance and rumen fermentation of Jersey cows grazing ryegrass pasture during spring. Anim. Feed Sci. Technol. 241:121-132. 10.1016/j.anifeedsci.2018.04.025. van Zyl, M., R. Meeske, G. D. J. Scholtz, and O. B. Einkamerer. 2014. The effect of lucerne (Medicago sativa) hay quality on milk production and composition of Jersey cows. S. Afr. J. Anim. Sci. 44:S25-S30. 10.4314/sajas.v44i5.6.

Velik, M., R. Baumung, and W. F. Knaus. 2008a. Maize silage as an energy supplement in organic dairy cow rations. Renew. Agric. Food Syst. 23:155-160. 10.1017/S1742170507002104.

Velik, M., A. Steinwidder, and W. F. Knaus. 2008b. Lupin-pea-cereal mixture or cereals as supplements for organic dairy cows. Biol. Agric. Hortic. 25:339-351. 10.1080/01448765.2008.9755060.

Weisbjerg, M. R., M. K. Larsen, L. Hymøller, M. Thorhauge, U. Kidmose, J. H. Nielsen, and J. B. Andersen. 2013. Milk production and composition in Danish Holstein, Danish Red, and Danish Jersey cows supplemented with saturated or unsaturated fat. Livest. Sci. 155:60-70. 10.1016/j.livsci.2013.04.008. 